\title{
Seed Characteristics and Proximate Analysis of Wild Castor Plant from Sokoto State
}

\author{
*Aisha U, ** B. L Aleiro, ** K. Shehu ***Hauwa B., ***Sumayya B. I., \\ ***Shuaibu M. and ***M.B. Abubakar \\ *Ahmadu Bello Academy, Sokoto \\ **Botany Unit, Usmanu Danfodiyo University, Sokoto \\ ***Department of Natural Sciences, The Polytechnic of Sokoto State, Sokoto
}

\begin{abstract}
In this study, castor seeds were collected fromWamakko local government Area of Sokoto and the seeds were subjected to different studies which included seed characteristics, proximate analysis and mineral composition. The typical castor seed in Sokoto was found to have a range of 1- 8 bunch, each bunch contains several pods ranging from 30-56 with an average of 43 pods per bunch. The proximate analysis of the seed was found to contain $28 \%$ carbohydrate, $11 \%$ protein, $3.5 \%$ ash, $1.78 \%$ nitrogen, 1.0 crude fibre respectively. The paper concludes that Sokoto state has good potential for large cultivation of castor plant and consequently joining the castor seed market.
\end{abstract}

Keywords; castor seeds, proximate analysis, seed characteristics, mineral composition

\section{Introduction}

The castor plant due to its unique characteristics is attracting a lot of interest as area of current research all over the world. Internationally, it is estimated that over 800,000 metric tons of castor seed are produced annually (Redmond, 2008).Primary exporters are China, Thailand, Russia and Sudan but Brazil and India grow significant quantities which are not traded internationally while the largest importers are the US, France and UK (Ahnet al., 2007). The global trade in this product is put at $\$ 5 \mathrm{~b}$ (Redmond, 2008). The castor been contains 45 $55 \%$ castor oil which makes it indispensable in tanning of skins, production of cosmetics, pharmaceuticals and insecticides (Ahnet al., 2007).

Castor seeds are nearly flattened and oval but differ in size) and colour (Fakhri, 1989). The size of castor seed has been reported to vary from a few millimetres long to about $2 \mathrm{~cm}$ in the giant species (Das et al., 2000). It has been reported that seeds from Nigeria and Kenya have an average weight of 59.2 and $61.3 \mathrm{~g}$ per hundred seeds respectively (Fakhri, 1989). Small sized seeds weighing 16g per hundred have been reported in India (Willcox, 2000).

There are an astonishing numbers of industrial application for castor oil and its derivatives and new ones are continually been discovered (Raymond, 1996).

Sokoto state has a favourable climate for the large cultivation of castor plant as it is known to do well in the hot climate conditions and is drought tolerant (Iyothiet al., 2006). The castor plant has potential for export. In fact, the Yobe State government through the sponsorship of the EU recently embarked on a large scale production intended to engage about 100,000 farmers in the state. This effort is expected to boost the state economy as a major revenue generator and provider of job opportunities.

In Nigeria, no commercial castor oil is produced and the industries that need it depend on imported oil, which is very expensive (Das et al., 2000). The need to promote the production of castor bean seed as an alternative to synthetic seed products is therefore beyond any emphasis.

\section{Seed Collection and Handling}

\section{Materials And Methods}

Castor fruit pods were collected between December 2009 and June, 2010 from Wamakko Local Government Area of Sokoto Stateon Longitude $5^{0}$ and Latitude $15^{\circ}$. The number of pods per plant was counted and sun dried to facilitate seed removal. The dried pods were then crushed and the number of seeds per pod was determined. The shelled seeds were cleaned by removing all debris, parked in large envelopes and kept in wooden cabinet.

\section{Evaluation ofSeed characteristics}

The size, shape, colour, weight and density of castor seeds were evaluated in the laboratory. The length and width of ten seeds were determined using veneer calliper and the average taken. The colour was visually observed and the mass determined using a digital electronics balance (Citezen scales PVT LTD). The volume 
of kerosene displaced by hundred castor seeds in a $50 \mathrm{~cm}^{3}$ measuring cylinder was determined. The density was then evaluated using the mass and volume.

\section{Analyses of Mineral composition in castor seeds}

Dried castor seeds $(1850 \mathrm{~g})$ were crushed to a paste using mortar and pestle. The castor seed paste was analysed to determined its mineral content. The minerals analysed were nitrogen, potassium, sodium, calcium and magnesium.

\section{Determination of Nitrogen in the castor seed paste}

In the determination of nitrogen Macro kjeldahl method was used.

Two grams of the sample were poured in a Macro kjeldahl flask and twenty ml of distilled water was added. The flask was swirled for a few minutes and allowed for 30 minutes to prevent foaming. One tablet of mercury was added, Fifty $\mathrm{ml}$ of concentrated $\mathrm{H}_{2} \mathrm{SO}_{4}$ was also added through an automatic pipette. The flask was heated cautiously at low temperature of $45^{\circ} \mathrm{C}$ on the digestion stand . When water has been removed and frothing has ceased, the temperature of the flask was increased until the digest was cleared. The digest was boiled for 5hours. Heating was regulated during boiling so that $\mathrm{H}_{2} \mathrm{SO}_{4}$ condenser is about half way up the neck of the flask. The flask was allowed to cool and Fifty $\mathrm{ml}$ of distilled water was added to the flask. Ten $\mathrm{ml}$ of the aliquot was carefully transferred into a macro kjeldahl flask $750 \mathrm{ml}$. Twenty $\mathrm{ml}_{3} \mathrm{BO}_{3}$ indicator solution was added into Fifty $\mathrm{ml}$ Erlemmeyer flask which was then placed under the condenser of the distillation apparatus. Twenty $\mathrm{ml}$ of $40 \% \mathrm{NaOH}$ was added to the macro kjeldahl flask through a funnel on the stop cork and distillation was commenced. The condenser was kept cool at $30^{\circ} \mathrm{C}$ allowing sufficient cold water to flow through and heat was regulated to minimize frothing and prevent suck back. 40ml distillate was collected and distillation was stopped. $\mathrm{NH}_{4}-\mathrm{N}$ in the distillate was determined by titrating with $0.01 \mathrm{~N}$ standard $\mathrm{H}_{2} \mathrm{SO}_{4}$ using burette graduated at $0.1 \mathrm{ml}$ intervals. The colour changed at the end point from green to pink. The percentage Nitrogen in the sample was calculated.

Thus -

$\%$ nitrogen $=\frac{\text { TVX N X } 0.014 \mathrm{X} \text { VOL } . \mathrm{X} 100}{\text { mass of sample } \mathrm{X} \text { aliquot of digest }}$

\section{Determination of Potassium}

Potassium and sodium were determined by flame photometer and was set for potassium by inserting appropriate filter (usually of $788 \mathrm{~nm}$ in wavelength). The instrument was set to $100 /$ transmittance by feeding $10 \mathrm{pm} \mathrm{k}$ solution. All the standard solutions were ran and standard curves prepared by plotting transmittance reading against concentration of standard potassium solution. The seed extract was run and the amount of potassium present in the sample per $100 \mathrm{~g}$ oven dry mass of the sample was calculated by getting potassium concentration in the extract from standard curve. All dilutions were considered in making the calculations.

\section{Determination of sodium}

The flame photometer for sodium (Na) was set by inserting filter (usually of $589 \mathrm{~nm}$ wavelength). The instrument was set to $100 \%$ transmittance by feeding 10ppm sodium ( Na) solution. The steps were repeated 3-5 times for potassium (K) determination.

\section{Determination of calcium and magnesium}

One millilitre aliquot of the extract was put into titration flasks using pipette and diluted to Twenty $\mathrm{ml}$ with distilled water. Five $\mathrm{ml}$ of buffer solution and 3drops each of $\mathrm{KCN}, \mathrm{NH}_{2} \mathrm{OH} . \mathrm{HCl}, \mathrm{K}_{4} \mathrm{FE}[\mathrm{CN}]_{6}$ and triethanolamine were added. A few minutes was allowed for reaction to take place. Three drops of EBT indicator were added to the solution and titrated with (EDTA) in the above manner to the permanent blue colour. Calcium + magnesium were obtained by EDTA Titration method.

The $\mathrm{Ca}$ and $\mathrm{Mg}$ were obtained in the sample after making up to a definite volume. Aliquots of this extract were used to determine $\mathrm{Ca}+\mathrm{Mg}$ and $\mathrm{Ca}$ alone.The value for $\mathrm{Mg}$ was obtained as the difference.

\section{Proximate analysis of the castor seed paste}

Proximate analysis of the castor seed paste was carried out in the Agriculture laboratory of Usmanu Danfodiyo University to determine the percentage of crude protein, lipid, ash moisture content, fibres, and carbohydrate of the seed paste.

\section{Determination of the crude protein in the castor seed paste}

The method used was the Macro kjeldahl method the principle was that when protein is boiled with concentrated sulphuric acid and a tablet of kjeldahl catalyst so the $\mathrm{H}_{2} \mathrm{SO}_{4}$, convert all forms of nitrogen to ammonia sulphate. Subsequently addition of an excess amount of $\mathrm{NaOH}$ in a close system neutralizes the acid 
and releases ammonia which is distilled into boric acid solution, and titrated against $0.01 \mathrm{~N} \mathrm{HCl} \mathrm{or} \mathrm{H}_{2} \mathrm{OH}_{4}$ end point from green to pink.

Three steps were involved in this analysis. They are digestion, distillation and titration

Digestion

Two grams of the sample was weighed and placed in the bottom of a kjeldahl flask. Twenty (20) $\mathrm{ml}$ of concentrated $\mathrm{H}_{2} \mathrm{SO}_{4}$ was added to the flask which was swirled to soak the sample. One tablet of kjeldahl catalyst was added to it. The flask was heated gently on an electric heater in a fumes chamber until the solutions become blackened and then clear so as to convert any nitrogen present to ammonium sulphate and organic matter to carbon [iv] oxide.

\section{Distillation and Titration}

Ten mills of the digest sample were pippetted in to twenty mills of round bottom flask was heated in the macro kjeldahl apparatus for ten minutes. Twenty mills of boric acid indicator was placed in a $100 \mathrm{ml}$ conical flask and placed under the condenser Such that the condenser tip was above $4 \mathrm{~cm}$ to the surface followed by Twenty (20) mills of $40 \% \mathrm{NaOH}$ solution. The $\mathrm{NaOH}$ solution was let in carefully through the funnel and little was left behind to prevent the escape of ammonia. Steam was then let through for about 3 minutes [until the amount of liquid in the receiving conical flask was twice that of what it was at the beginning of the distillation]. This was then titrated with $0.01 \mathrm{~N} \mathrm{HCl}$ to end point and the titre value was recorded. The crude protein content was calculated from the titre value using the following relation

$\%$ nitrogen $=\frac{\text { TVXnaX } 0.014 \text { XvolX } 100}{\text { massof sampleX } m^{\prime} \text { sofaliquot }}$

$\%$ of nitrogen $\mathrm{x} \mathrm{CF}=\%$ crude protein

\section{Crude lipid determination}

The analysis was carried out using the method of Oyenuga (1978).

Two grams of the dried sample was placed into a thimble with the opening plugged with cotton wool as an alternative, the sample was wrapped in a filter paper. The thimble was then introduced into a barrel of the extractor and a 500L round bottom flaskof known mass (156.1g) was filled with petroleum ether up to $3 / 4$ its volume .The flask was then heated at $50^{\circ} \mathrm{C}$ for 6 hours of the total extraction after which fat was evaporated. The residue [crude lipid] left in the flask was then weighed to know the crude lipid content.

$\%$ lipid $=\frac{\text { massoft hecrudelipid }}{\text { massof sample }} \quad \mathrm{X} 100$

\section{Ash content determination}

The crucible was first washed, dried in an oven at $180^{\circ} \mathrm{C}$ for 30minutes cooled and then weighed $\left(\mathrm{M}_{\mathrm{o}}\right.$ $[\mathrm{g}])$. Two grams of sample was placed in the crucible and weighed, $\left(\mathrm{M}_{1}[\mathrm{~g}]\right)$ then the crucible was transferred into the muffle furnace, whose Temperature was set at $600^{\circ} \mathrm{C}$ and allowed to stay for 3 hours, until the content became white after which the crucible was cool in a desiccators and weighed $\left(\mathrm{M}_{2}[\mathrm{~g}]\right)$.

The percentage ash content was then calculated using the relation below;

$\%$ ash content $=\frac{\text { mass ofash }[\mathrm{g}]}{\text { massofsam ple }[\mathrm{g}]} \times 100$

$=\frac{M 2-M 0}{M 1-M 0} \times 100$

\section{Moisture content determination}

The method of Oyenuga (1978) was employed as follows:

The sample weighed $\left(\mathrm{M}_{1}\right)$ was heated in an oven at $105^{\circ} \mathrm{C}$ for $24 \mathrm{hrs}$ and cooled in a desiccator for 15 minutes then weighed, $\left(\mathrm{M}_{2}\right)$. The crucible was then returned into the oven and weighed after $3 \mathrm{hrs}$ for as many times as possible until a constant value was obtained.

$\%$ moisture content $=\frac{\text { lossinmassbydryingX } \quad 100}{\text { massof sample }}$

\section{Crude fibre determination}

$100 \mathrm{ml}$ of $1.25 \% \mathrm{H}_{2} \mathrm{SO}_{4}$ digestion mixture was added to Two grams of sample in $250 \mathrm{ml}$ conical flask, followed by occasional shaking for 30mins. The mixture was filtered through a filter paper. $100 \mathrm{mIs}$ of boiling water, $100 \mathrm{mls} 1.25 \% \mathrm{NaOH} 20$ mills of ethanol and $20 \mathrm{ml}$ of petroleum ether were used to wash it. The residue was dried at $100^{\circ} \mathrm{C}$ to constant mass in the oven, followed by ashing at $550^{\circ} \mathrm{C}$ to burn off the crude fibre content. The ash obtained was weighed and the crude fibre content was determined from the decrease in mass. $\%$ crude fibre $=$ mass of crude fibre in digested cake divided by mass of sample used, multiplied by a hundred . 


\section{Carbohydrate determination}

When all other analysis has been carried out, percentage Carbohydrate can be calculated by subtracting the sum of lipid, crude protein, fibre and ash from 100. Whatever remains is the Percentage carbohydrate.

Thus $100 \%$ - (\%crude protein $+\%$ fibre $+\%$ ash $+\%$ lipid $)=\%$ carbohydrate

\section{Results}

\section{Result of Physical Seed Characteristics}

Wild Ricinus communis in Sokoto was found to bear average of six bunches per plant with a range of thirty to fifty pods per bunch. Each pod contains only three seeds. The mean seed length was $83 \mathrm{~mm}$ and the width $42 \mathrm{~mm}$. The mean seed mass was $0.18 \mathrm{~g}$. Average seed volume was $0.33 \mathrm{ml}$ while the mean density was $0.52 \mathrm{~g} / \mathrm{ml}$. The colours of the seeds found were mainly of black and light brown with white stripes.

Table; 1 Result of the physical characteristics of castor

\begin{tabular}{|l|l|}
\hline Property of castor examined & Result \\
\hline Average bunches per plant & 6 \\
Pods per bunch & 30 to 50 \\
Seeds per pod & 3 \\
Mean seed length & $83 \mathrm{~mm}$ \\
Mean seed width & $42 \mathrm{~mm}$ \\
Mean seed mass & $0.18 \mathrm{~g}$ \\
Mean seed volume & $0.33 \mathrm{ml}$ \\
Mean seed density & $0.52 \mathrm{~g} / \mathrm{ml}$ \\
Seed colour & Black and light brown with white stripes \\
\hline
\end{tabular}

Results of Analysis of the mineral content

Results of the analyses of the mineral content of the seed paste is summarised in table 2

Table 2; Castor seed mineral composition

\begin{tabular}{cc}
\hline Mineral & Composition $(\mathrm{mg})$ \\
\hline $\mathrm{Na}$ & 45 \\
$\mathrm{~K}$ & 1850 \\
$\mathrm{Mg}$ & 1.2 \\
$\mathrm{P}$ & 2.56 \\
$\mathrm{Ca}$ & 0.35 \\
\hline
\end{tabular}

Potassium $\{\mathrm{k})$ was the highest mineral contained in the castor seed $(1850 \mathrm{mg} / \mathrm{ml})$ followed by Sodium $(\mathrm{Na})$ with $45 \mathrm{mg} / \mathrm{ml}$, then Phosphorus $(\mathrm{P})(2.56 \mathrm{mg} / \mathrm{ml})$ and Magnesium $(\mathrm{Mg})$ with $1.2 \mathrm{mg} / \mathrm{ml}$. The least mineral contained was Calcium with a value of $0.35 \mathrm{mg} / \mathrm{ml}$.

Result of Proximate analysis of the castor seed paste

Result of proximate analysis of the castor seed paste is shown in Table 3

\begin{tabular}{ll}
\hline $\begin{array}{l}\text { Table; } 3 \text { proximate analysis of castor seed paste } \\
\text { \% Composition }\end{array}$ \\
\hline Ash & \\
\hline Crude fibre & 3.50 \\
Crude protein & 1.00 \\
Lipid & 11.11 \\
Carbohydrate & 55.50 \\
& 28.39 \\
\hline
\end{tabular}

The ash content was $3.5 \%$, crude fibre $1.0 \%$, crude protein $11.11 \%$, the lipid content yielded $55.5 \%$ and carbohydrate content was $28.39 \%$.

\section{Physical properties}

\section{Discussion}

Theaverage mass of castor seed in Sokoto with a value of $0.18 \mathrm{~g}$ per seed is very much smaller than the Nigerian and Kenyan average which is put at $0.59 \mathrm{~g}$ per seed (Weis, 1971 and Mensah and Orchran, 2005) but in the range of small sized seeds weighing $0.16 \mathrm{~g}$ per seed as reported from India (Wilcox, 2000). The average 
length of giant sized castor seed species (2cm long) as reported by Weis (1971) was more than two times the length of those found in Sokoto state $(0.83 \mathrm{~cm})$. It was however in the range of those reported from Ghana 0.9 to $1.0 \mathrm{~cm}$ in length (Mensah and Orchan, 2005). The colours of black and light brown with white stripes of castor seeds found in Sokoto were similar to those found elsewhere (Willox, 2000), (Weis, 1971) and (Mensah and Orchran, 2005). The number of seeds per pod in Sokoto (3) was very much within the range ( 3 to 4 ) reported by Weis (1991). The average number of pods per bunch (43) and bunch per plant (6) in Sokoto was comparable to those from other regions such as India as reported by Weis (1991). The value also suggests good yield for castor plants from Sokoto.

The results presented in table 3 illustrate the content of various mineral contents; sodium ( $\mathrm{Na}$ ), magnesium $(\mathrm{Mg})$, phosphorous and calcium. Potassium shows high percentage composition of $1850 \mathrm{mg} / \mathrm{ml}$ which is greater than that of phosphorous, calcium and magnesium. The above mentioned nutrients contributed a lot in the development and growth of the plant Ricinuscommunis and could be a good source of fertilizer.

The results obtained from the proximate analysis of the seed cake of castor plant indicated a high percentage of lipid content of 55.5\% the high percentage lipid content showed that the plant (Ricinus communis) has the potential of yielding considerable amount of oil.

Carbohydrate content of the seed cake yielded (28.39\%) showed that the cake may be a very good source of energy (Carbohydrate) for both man and animals if detoxified.

The crude protein (11.11) also showed that the cake may be a very good source of protein. The ash content 3.5 shows highlight of the inorganic material present. It could be seen that high, percentage of ash content means high content of mineral while low content of minerals is indicated by the low percentage of ash content was indicated by the low percentage of ash content (Black, 1995).

\section{Conclusion}

R. communis plants in Sokoto has good yield of seeds with an average of 720 with a mass of $129.6 \mathrm{~g}$ per plant. The study suggests that the seed has good source of carbohydrate for human and animal consumption. It is also a good source of fertilizer and a possible good oil yield that has wide variety of uses.

\section{Recommendations}

In view of the high potentials of $R$. Communisas a useful crop in Sokoto, further study is recommended on the safety of the use of castor products.

\section{References}

[1]. Ahn, Y.J, Vang, L. Mckeon, T. and Chen G. Q (2007); High frequency plant regeneration Adventitious shoot formation in castor (Ricinus cummunis) L In vitro cellular developmental biology plant; 43(1); 9-15.

[2]. Black, C. A. (1965). Methods of soil Analysis Agronomy part 2 America, Soc, Agronomy. Madison, Wisconsin. 14-15.

[3]. Das, S. C. Isichei, C.O., Okwuasaba, F. K.andUguru, V. E.(2000); Clinical Pathological and toxicological studies of the effects of RICOM- 1013 - Journal of Ricinus communisVar Minor on Women. Volunteer on Rodents. phytother Res, 14 (1) 15-19.

[4]. Fakhri, Z. I. (1989); Mean diameter in skin test for castor bean extract. In castor bean allergic workers of eastern Sudan Journal of Occupational Medicine; 39 (4): 144 -146.

[5]. Iyothi, M., Thatikunta, R. and Akuia, B. (2006); Identification of Castor, Ricinus communis L, Genotypes for Rainfed Conditions. Oilseeds Reseach; 23 (1): 9-15.

[6]. Mensah, B. and Orchran, (2005) Physicochemical Characteristics of Castor Oil From Local Wild Castor Plant in Ghana. Ghana Journal of Science. Accra. 45, 41-44.

[7]. Oyenuga, V. A. (1978) Nigerian's Food and Feeding Stuff, University Press Ibadan, Nigeria PP 27-33.

[8]. Redmond, W. A. (2008); Castor oil Microsoft Encanta (DVD) Microsoft Corporation,

[9]. Weis, E, A (1991) Castor Sesame and SafflowerLeornardo Hill BooksInternational Textbooks Co., LTD London. 21 -24

[10]. Willcox, Michael (2000); Soap in Hilda Butler; Poachers, perfumes, and Soaps. (10 ${ }^{\text {th }}$ edition). Dordrecht; Kluwer Academic publishers' pp 453. 